\title{
DESCENT DOWN THE AVENUE OF DREAMS
}

Victoria Armour-Hileman, award winner

That first year I was always trying to save you.

There was the beating they gave you

before you came to live with us.

Perfect miniature of a derelict,

careless in your bones, a stick and twig starveling, slumped in hideous baby postures,

wrinkling your third eye-that blue bulge

where you'd been hit. You were long,

thin, and colorful as a stained glass window.

Love starved the doctor called it.

Babies know, he said. Then the asthma.

Throwing on robes at midnight, Mother

and I would rush you to the shower, one of us holding you up like a banner, the other turning on the steam until the room was filled with hot towels

of vapor, suffocating us, choking up the mirror. You kicked, your hands beating the air-frogs leaping at the sides of a glass cage. I held my breath with you

as long as I could. And when you were better I worried you with tenderness, kissing your baby cheeks, burrowing my face in the clean smell of your warm, powdery shirts. At eleven 
must have been ridiculous, pushing away all hands, bossing anyone who would listen. I carted you around on one hip like the purses worn by high school girls. Ugly, I shoved my hair

behind my ears, stringy as wet dental floss. I chewed gum with tense, serious arrogance. I think I mixed us up, thought somehow I was the wizened starveling, suffocating,

wounded. Can you forgive me for loving only what I saw of myself in you? I know it is more terrible than that. Though sometimes even now

I startle out of sleep, and run down the hall, hearing that blue-faced silence only to remember we both moved out years ago. And when they told me what you had done

I followed you in my dreams, down the dark rich avenue of parked cars. And the hand was mine, raising the thick pipe, mine the first shattering breath, as the glass began to fly. 